\title{
FATTY FOOD, OR FATTY FOOD SIMULANTS AND PET PACKAGING INTERACTIONS - STUDY WITH DETA
}

\author{
Aleksandra Porjazoska Kujundžiski ${ }^{1, ~ *, ~ T o m a ~ G r c ̌ e v ², ~}$ \\ Dragica Čamovska², Maja Cvetkovska²
}

\author{
${ }^{1}$ Faculty of Technical Sciences, International Balkan University, \\ Taško Karadža 11A, Skopje, Republic of Macedonia \\ ${ }^{2}$ Faculty of Technology and Metallurgy, Ss. Cyril and Methodius University, \\ Rugjer Bošković 16, Skopje, Republic of Macedonia \\ aporjazoska@ibu.edu.mk
}

\begin{abstract}
Dynamic electrical thermal analysis (DETA) is considered as a valuable technique for determination of polar polymer structure or changes in the polymer structure as a result of different treatments. Therefore, with this study, we wanted to check whether this technique can indicate structural changes in the PET packaging material in contact with specific media. Positive response give the opportunity to use the study of PET packaging dielectric properties after a programmed contact with some medium, to indicate possible interactions between packaging material and the medium, or packaging and foodstuff. It is also known that official simulants may have some drawbacks as migration of the potential contaminants depends on the interaction between the simulant and packaging and thus the values for measured migration could be exaggerated or too low.

The possibility of DETA to indicate structural changes in the packaging material give also the opportunity to adjust the aggressiveness of some medium to the packaging, that is, some solvent, or mixture of solvents with different polarity, and thus to choose the most appropriate simulant - medium which will behave in the same way as the foodstuff.

In this study we have chosen several conventional fatty food simulants: olive oil, isooctane, $3 \%$ acetic acid, and ethanol, and using the DET analysis we compared the influence of these media and the real foodstuff (mayonnaise) on the structure of poly(ethylene terephthalate) (PET) food containers.
\end{abstract}

Keywords: DETA; PET containers; structural changes; fatty food simulants

\section{ИНТЕРАКЦИИ МЕЃУ АМБАЛАЖА ОД РЕТ И МАСНА ХРАНА ИЛИ СИМУЛАНТИ ЗА МАСНА ХРАНА - АНАЛИЗА СО ФЕТА}

Динамичката електротермичка анализа (DETA) е инструментална техника која може да укаже на одредени карактеристики на структурата и на промените во структурата на поларните полимери како последица на различни третмани. Во овој труд е направен обид DETA да се искористи за регистрирање на структурни промени на амбалажа за храна произведена од полиетилентерефталат (РЕТ) при контакт со одредени медиуми. По програмиран контакт со специфичен медиум, регистрирани се промени во диелектричните својства на полимерот, што укажува на промени во структурата на амбалажата од РЕT, а со тоа и на можни интеракции помеѓу полимерниот материјал и медиумот и/или реална храна. Исто така, познато е дека користењето на конвенционалните симуланти за храна понекогаш има слабости, бидејќи миграцијата на потенцијаните контаминанти зависи од интеракцијата помеѓу симулантите и 
амбалажата, така што измерените вредности за миграцијата можат да бидат поголеми од реалните, или премногу мали.

Користењето на DETA при одредувањето на структурните промени во материјалот за пакување едновремено нуди можност за регулирање на агресивноста на одредени медиуми во однос на амбалажата со употреба на соодветни растворувачи или комбинација на растворувачи со различна поларност. Тоа значи дека овој метод би можел да помогне за селекција на најпогоден симулант, медиум кој би се однесувал на ист начин како и реалната храна.

За оваа студија како конвенционални симуланти за масна храна беа избрани маслиново масло, изооктан, 3\% оцетна киселина и етанол, а со помош на DETA беше споредувано влијанието на овие медиуми, како и влијанието на реална храна (мајонез) врз структурата на садовите за храна произведени од РЕТ.

Клучни зборови: DETA; садови за храна од PET; структурни промени; симуланти за масна храна

\section{INTRODUCTION}

The primary role of packaging materials is to provide a suitable foodstuff protection from chemical, biological and physical influences, wherewith will contribute to the postponement of the product putrescence, extension of the shelf-life, as well as to the maintenance or increase of the food quality and safety.

Due to the wide range of their flexibility, the possibility of processing in different sizes and shapes, thermal sealability, cost advantages, and satisfactory barrier capabilities, the usage of plastics as packaging material has been considerably increased. On the other hand, plastics in a contact with the foodstuff are not completely inert, they allow mass transport (permeation, migration and sorption) of low molecular weight substances from packaging material to the food, and vice versa [1-3].

According to the international European regulations, any physical or chemical interactions concerning polymer packaging and the products, used in pharmacy, medicine, cosmetic and food industry, should be minimized or completely absent. Consequently, improvement of the existing and development of new prompt methods for identification and determination of additives in the polymer packaging material represents a permanent challenge [4-6].

In general, as the real food is too complex for migration measurement, simpler model media, so called food simulants, have been used, and they are defined in the regulations $[7,8]$. In the case of fatty foods, the official simulants are: olive oil, acetic acid, ethanol, isooctane, and mixtures of triglycerides, used in the proper conditions (time and temperature). Anyway, the application of the official simulants may have some drawbacks as migration of the potential contaminants depends on the interaction between the simulant and packaging. For example, isooctane (which is an authorized fatty food simulant) is an apolar solvent and strongly interacts with polyolefins, while more polar materials may not interact with isooctane. Therefore the values for measured migration could be exaggerated or could be too low. So, the efforts in tailoring the appropriate media for a food simulant become of the tremendous importance $[9,10]$.

Again, the migration process from packaging material is closely related to the structure of the material, while the structural changes of the polymer could be triggered by the penetration of the media or the components from the media (foodstuff or food simulant) in contact with the packaging $[11,12]$.

The possibility of dynamic electrical thermal analysis (DETA) to indicate structural changes in the polar polymer packaging material give the opportunity to adjust the aggressiveness of some medium to the packaging, that is, some solvent, or mixture of solvents with different polarity. In that fashion, the selected simulant - medium will behave in the same way as the foodstuff $[3,9,10]$.

In this study we have chosen several conventional fatty food simulants: olive oil, isooctane, 3\% acetic acid, and ethanol, and 
using the DET analysis we compared the influence of these media and the real food stuff (mayonnaise) on the PET structure.

Dielectric properties reflex the behavior of the polymer in the electric filed. Dielectric constant and dielectric losses which are the indicators of the dielectric properties depend on the chemical composition and structure of the polymer, that is, on their dipole moment, the temperature, the frequency and the voltage of the applied $a c$ electrical field [13-15].

The relationship between dielectric properties and structure of the polymers gives the opportunity of DETA to be used as a study technique for polymer structure and structure changes. On the other hand, the changes in a polymer structure are closely related to many other properties, like mechanical features, resistivity toward different media, gasses and liquids permeability, relevant for the polymer application. So, the registered changes in the dielectric properties of a polymer material could indicate a possible migration of potential contaminants from the polymer to the foodstuff or a sorption of food components into the packaging material [13-15]. The feasible interaction between polymers and the foodstuff can contribute to the quality of the packaging material and the quality of the food as well.

\section{EXPERIMENTAL}

\subsection{Materials}

PET food containers used for the purpose of this study were transparent and colorless commercial samples.

T a b 1 e 1

Testing conditions for PET food containers at different time and temperatures, in contact with fatty food simulants

\begin{tabular}{|c|c|c|}
\hline Simulant / foodstuff & Testing time & Temperature \\
\hline \multirow{6}{*}{ Olive oil } & \multirow{2}{*}{$24 \mathrm{~h}$} & $5^{\circ} \mathrm{C}$ \\
\hline & & $40^{\circ} \mathrm{C}$ \\
\hline & \multirow{2}{*}{10 days } & $5^{\circ} \mathrm{C}$ \\
\hline & & $40^{\circ} \mathrm{C}$ \\
\hline & 1 month & room \\
\hline & 3 months & room \\
\hline \multirow{4}{*}{$3 \%$ acetic acid } & \multirow{2}{*}{$24 \mathrm{~h}$} & $5^{\circ} \mathrm{C}$ \\
\hline & & $40^{\circ} \mathrm{C}$ \\
\hline & \multirow{2}{*}{10 days } & $5^{\circ} \mathrm{C}$ \\
\hline & & $40^{\circ} \mathrm{C}$ \\
\hline \multirow{4}{*}{ Ethanol } & \multirow{2}{*}{$24 \mathrm{~h}$} & $5^{\circ} \mathrm{C}$ \\
\hline & & $40^{\circ} \mathrm{C}$ \\
\hline & \multirow{2}{*}{10 days } & $5^{\circ} \mathrm{C}$ \\
\hline & & $40^{\circ} \mathrm{C}$ \\
\hline \multirow{4}{*}{ Isooctane } & \multirow{2}{*}{$24 \mathrm{~h}$} & $5^{\circ} \mathrm{C}$ \\
\hline & & $40^{\circ} \mathrm{C}$ \\
\hline & \multirow{2}{*}{10 days } & $5^{\circ} \mathrm{C}$ \\
\hline & & $400 \mathrm{C}$ \\
\hline \multirow{4}{*}{ Foodstuff (mayonnaise) } & \multirow{2}{*}{1 month } & $5^{\circ} \mathrm{C}$ \\
\hline & & room \\
\hline & \multirow{2}{*}{3 months } & $5^{\circ} \mathrm{C}$ \\
\hline & & room \\
\hline
\end{tabular}

Maced. J. Chem. Chem. Eng. 32 (2), 283-297 (2013) 
Test samples for DET analysis with the diameter of $3 \mathrm{~cm}$, were cut from the containers, cleaned in ethanol and dried in a vacuum oven at $30^{\circ} \mathrm{C}$. Two test samples were used for each of the experiments, and when the obtained values varied from each other, the third sample was used.

Different samples are treated at different temperatures, different time, immersed in different media - simulants $(15 \mathrm{ml})$ : rectified olive oil (Sigma), 95-97\% ethanol (Merck), 3\% acetic acid (Merck), isooctane (Merck), and real foodstuff mayonnaise (for commercial use). The testing conditions are given within the scheme presented in the Table 1.

\subsection{Instruments}

Dielectric properties were measured on Polymer Laboratories Dielectric Thermal Analyzer (PL-DETA) equipped with parallel plate capacitance cell using $a c$ current. Thermal scans were performed from the room temperature to $180{ }^{\circ} \mathrm{C}$ at heating rates of 2,5 and $15^{\circ} \mathrm{C} / \mathrm{min}$.

Capacitance, $C_{\mathrm{p}}(\mathrm{pF})$, for the parallel equivalent electrical circuit, and phase lag, $\operatorname{tg} \delta$ as $D(\operatorname{tg} \delta$ $=\operatorname{tg}(90 \times D))$, were the measured parameters at 1 $\mathrm{kHz}$ and $200 \mathrm{mV}$ ac signal.

Dielectric permittivity, $\varepsilon$, and dielectric loss, $\varepsilon^{\prime}$, for the known thickness $(L, \mathrm{~cm})$ of the treated samples, and electrode area $(A=7.07$ $\mathrm{cm}^{2}$ ), were calculated by the equations:

$$
\begin{gathered}
\varepsilon^{\prime}=(11.3 \times L \times C \mathrm{p}) / A \\
\varepsilon^{\prime \prime}=\varepsilon^{\prime} \cdot \operatorname{tg} \delta
\end{gathered}
$$

FTIR spectra were obtained by FTIR Varian-600 instrument, FTIR (ATR) (PIKE MIRacle) at $550-4000 \mathrm{~cm}^{-1}$, with a resolution of $4 \mathrm{~cm}^{-1}$, and 16 scans.

\section{RESULTS AND DISCUSSION}

Figure 1 represents the dielectric permittivity, $\varepsilon^{\prime}$, and the phase lag, tangent $\delta$, dependences on temperature, $T$, at the heating rates of
2, 5, and $15^{\circ} \mathrm{C} / \mathrm{min}$. As it can be seen, heating rate of $2{ }^{\circ} \mathrm{C} / \mathrm{min}$ insures the appearance of a glass transition temperature. Namely, the maximum on a $\operatorname{tg} \delta-T$ curve appearing between $30^{\circ}$ and $70{ }^{\circ} \mathrm{C}$ belongs to the relaxation processes influenced by absorbed moisture and glass transition temperature.

In fact, the glass transition temperature corresponds to a shoulder on a $\operatorname{tg} \delta$ - $T$ curve in the temperature range between 60 and $70{ }^{\circ} \mathrm{C}$, which is in an agreement with literature data referring $T_{\mathrm{g}}$ for aPET (amorphous PET) at 67 ${ }^{\circ} \mathrm{C}$, and cPET (crystalline PET) at $81{ }^{\circ} \mathrm{C}[16$, 17]. In the temperature range from $20^{\circ}$ to 70 ${ }^{\circ} \mathrm{C}$, $\varepsilon^{\prime}$ takes values from 3.3 to 3.5 , confirmed by the literature data [18], with a dispersion, i.e. minimum, in the place where $\operatorname{tg} \delta$ curve shows maximum.

$\varepsilon^{\prime}-T$ dependences take an unconventional shape, with maximum which shift toward higher values when the heating rate increases. This phenomenon is a result of the cold crystallization process which could be confirmed by repeating the DET analysis on the same sample, when in the first heating cycle it was exposed up to 180 ${ }^{\circ} \mathrm{C}$ (Figure 2). As it can be seen in the second and third cycles the maximum disappeared.

The cold crystallization process, almost in the same temperature range, was also confirmed by DSC analysis [16, 17].

The ascendant amorphous feature of the samples and the cold crystallization process were also validated by FTIR spectra, Figures $3 \mathrm{a}$ and $3 \mathrm{~b}$. The characteristic valence vibration $\left(v_{\mathrm{s}}\right)$ for PET are: $2966 \mathrm{~cm}^{-1}(\mathrm{C}-\mathrm{H}), 1263$ $\mathrm{cm}^{-1}(-\mathrm{C}=\mathrm{O}), 727 \mathrm{~cm}^{-1}(\mathrm{C}(=\mathrm{O})-\mathrm{O}), 3545 \mathrm{~cm}^{-1}$ $(-\mathrm{OH}), 3268 \mathrm{~cm}^{-1}(-\mathrm{COOH})$, while the significant deformation vibrations $(\omega)$ appear at 1340 and $1370 \mathrm{~cm}^{-1}$.

Vibration at $1340 \mathrm{~cm}^{-1}$ correspond to the trans-conformation, while that at 1370 $\mathrm{cm}^{-1}$ is related to the gauche conformation of glycol $\left(-\mathrm{O}-\mathrm{CH}_{2}-\mathrm{CH}_{2}-\mathrm{O}-\right)$ linkages. Hence, the crystallization of the polymer can be observed according to the appearance and intensity of these bands. Namely, trans conformation is typical for crystalline phase, while gauche 


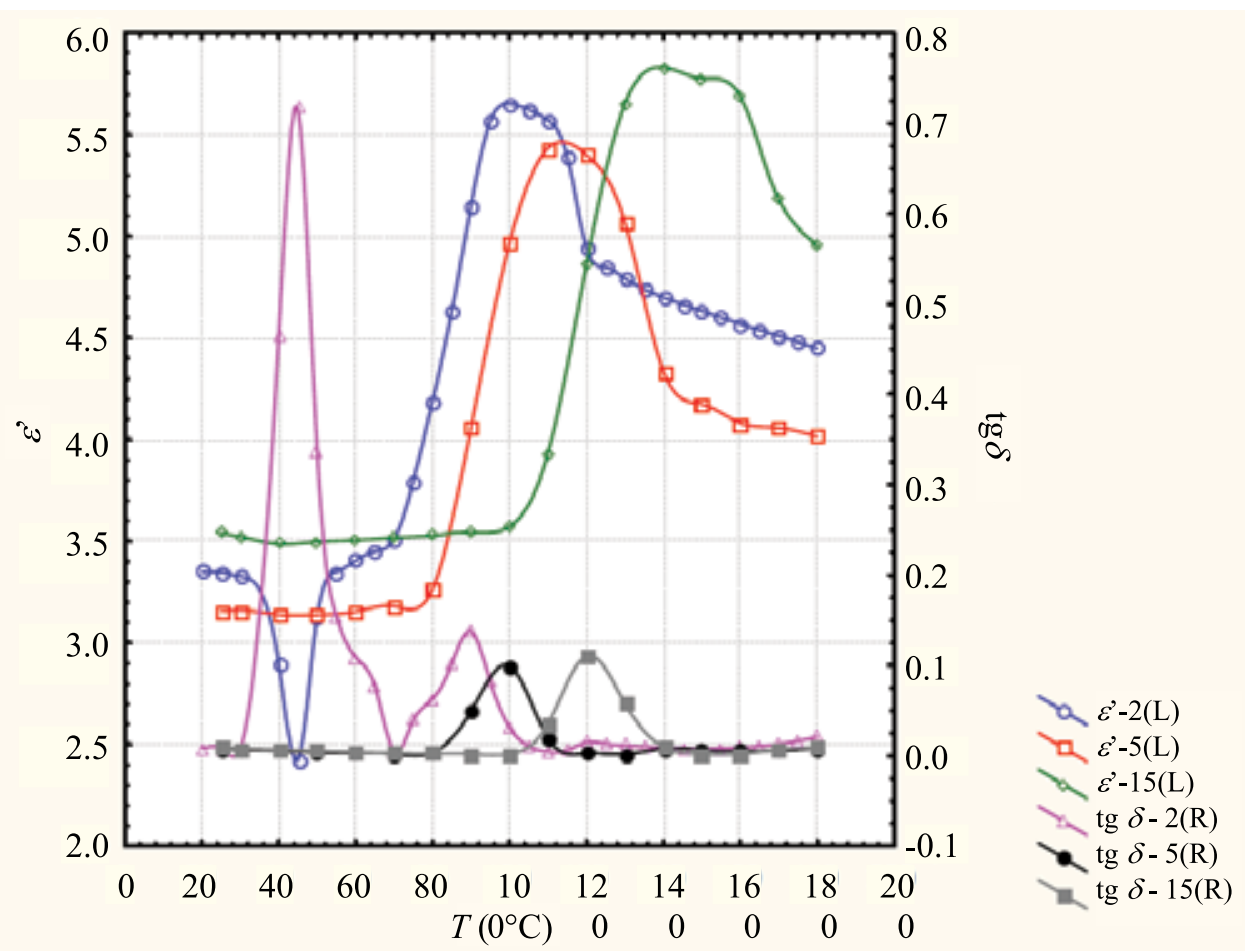

Fig. 1. $\varepsilon^{\prime}-T$ and $\operatorname{tg} \delta-T$ dependences, for PET food container, untreated, heating rates of 2,5 , and $15^{\circ} \mathrm{C} / \mathrm{min}$

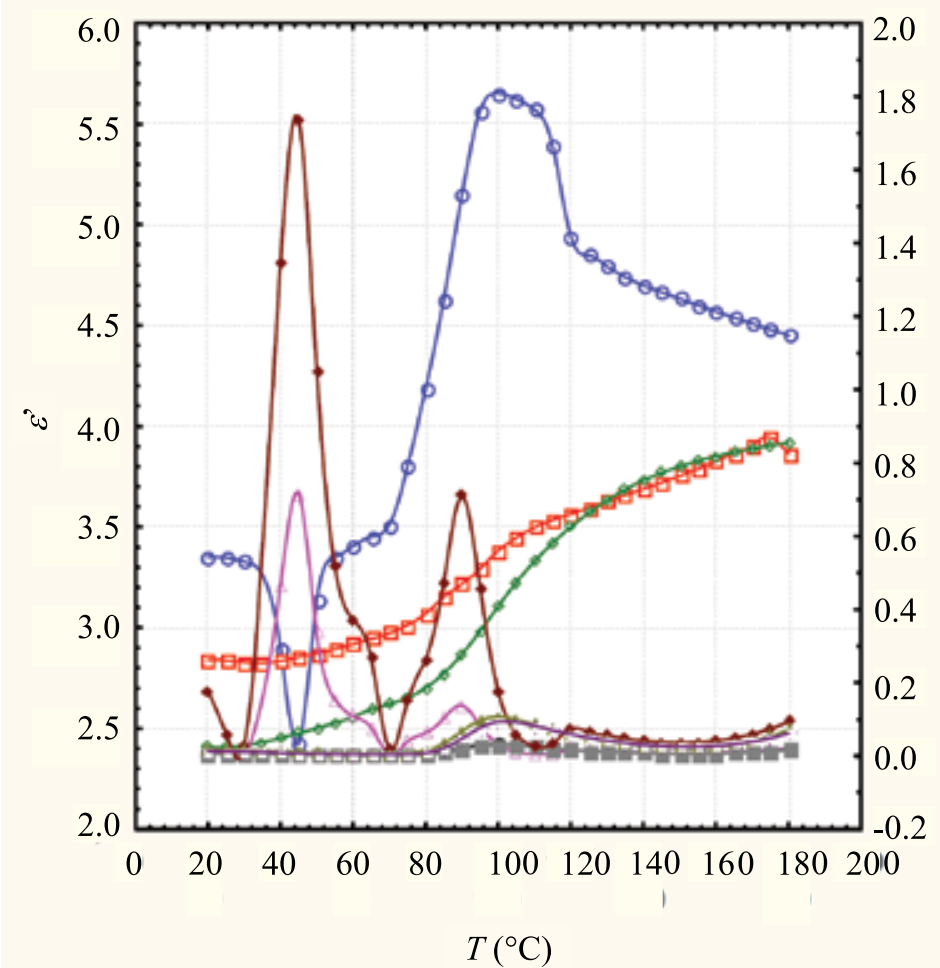

$n_{2}$
$\vec{a}$
कo

Fig. 2. $\varepsilon^{\prime}-T, \varepsilon "-T$ and $\operatorname{tg} \delta$ - $T$ dependences for PET food containers (three cycles), heating rate $2^{\circ} \mathrm{C} / \mathrm{min}$ 


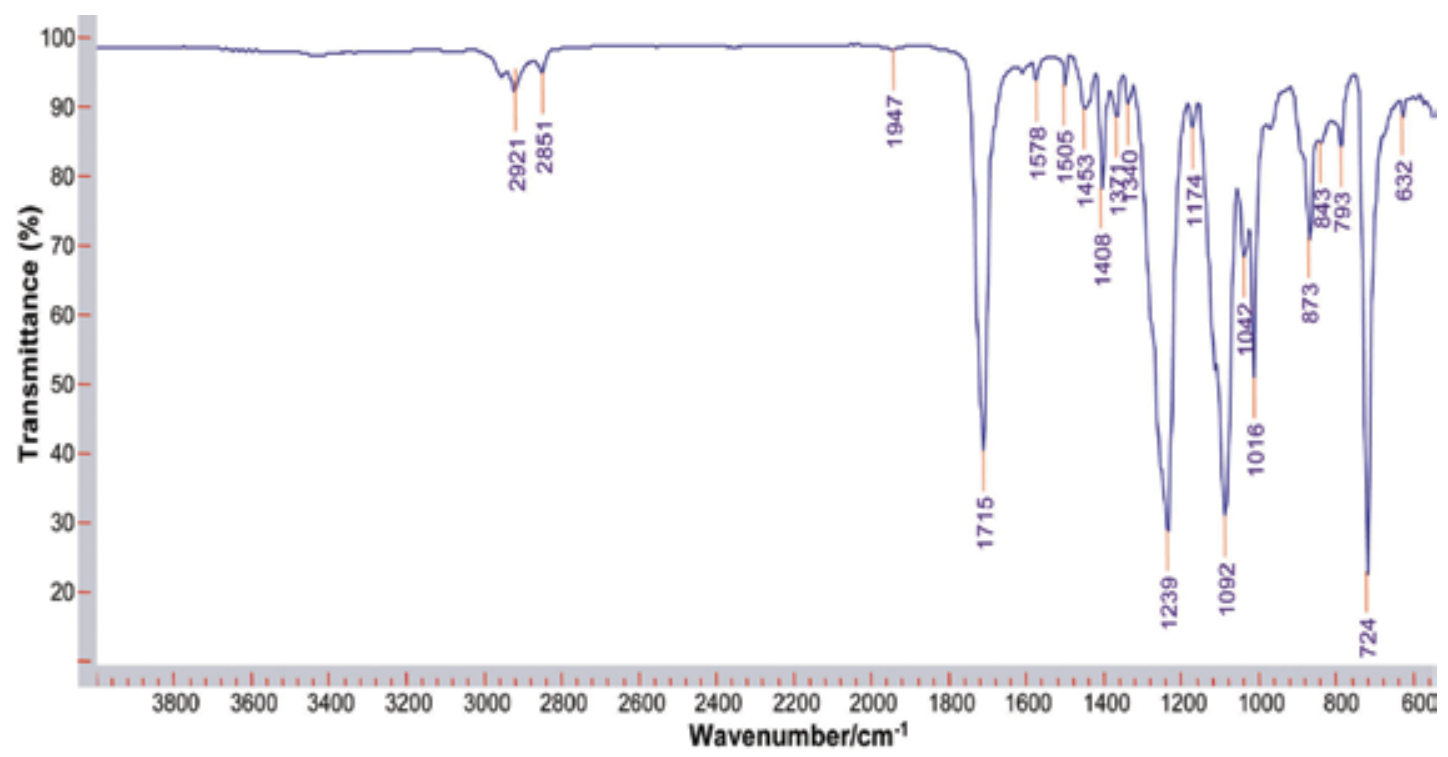

(a)

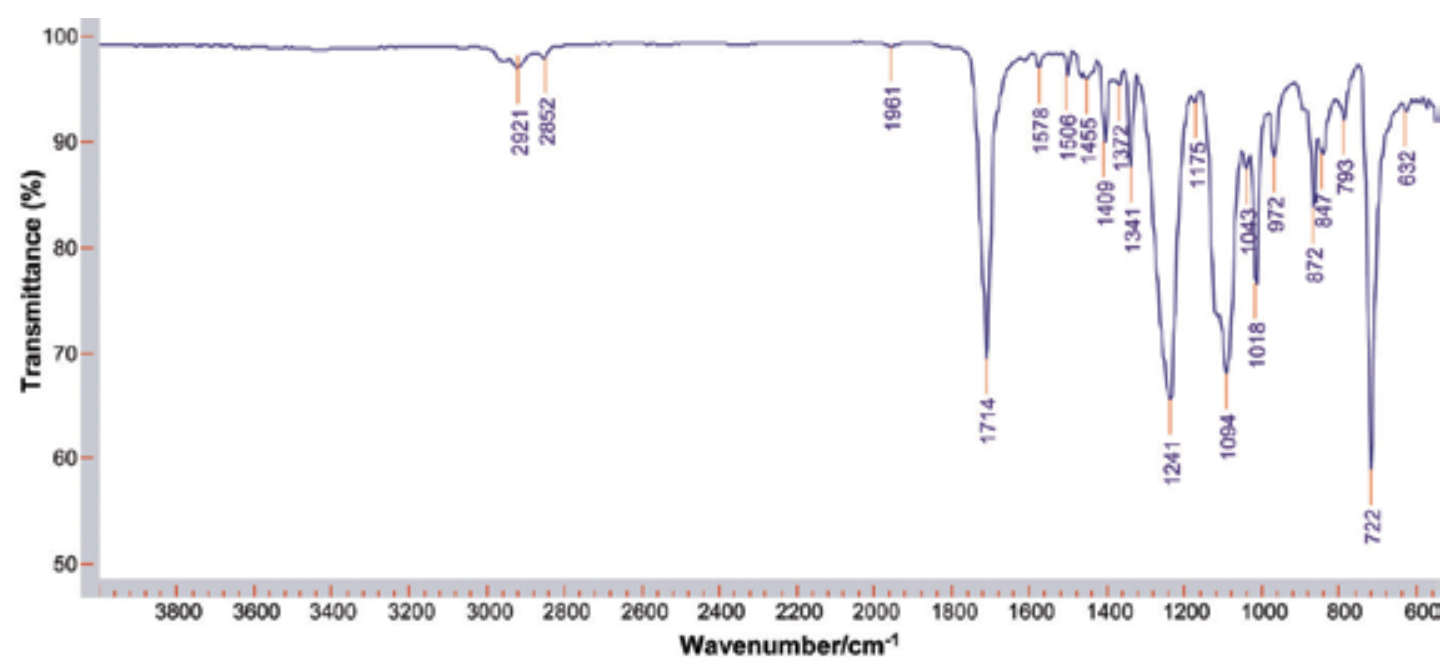

(b)

Fig. 3. FTIR spectrum for PET food container (a) and FTIR spectrum for PET food container after DETA analysis (denote after thermal treatment) (b)

conformation is representative for amorphous region. If we closely look at the spectra, it can been noticed that a vibration band at $1340 \mathrm{~cm}^{-1}$ became more intensive after a thermal treatment, i.e. after completed DET analysis (Fig. 3b). The fractions of the gauch and trans conformers can be calculated if the bands appearing at 1340 and $1370 \mathrm{~cm}^{-1}$ are normalized at $1410 \mathrm{~cm}^{-1}$ (characteristic for the vibration of phenylene ring), as it was previously implemented by Oureshi et al. [19].

Therefore, the contribution of the gauch and trans conformations before DETA stayed 59 and $41 \%$, and after the DET analysis was performed their participation was 14 and $86 \%$ respectively. Apparent evidence for the cold 
crystallization process is the transformation of a transparent sample at the beginning of the analysis into an opaque and milky white probe.

As it was previously shown on the Figure 1 , applying a heating rate of $\geq 5^{\circ} \mathrm{C} / \mathrm{min}$ during a DET analysis, relaxation processes in the temperature range to $80{ }^{\circ} \mathrm{C}$ were not registered. Thus, it was expected that implementing this heating rate during the DET analysis it would be possible to indicate the particular influence of a specific simulant in contact with PET sample in the above mentioned temperature range. This assumption was confirmed by the samples of PET container treated in olive oil, as one of the official fatty food simulants, for $2 \mathrm{~h}$, at the temperature of 50,100 and $175^{\circ} \mathrm{C}$, Figure 4.

Whereas the $\operatorname{tg} \delta$ - $T$ dependence obtained for a sample treated at $50{ }^{\circ} \mathrm{C}$ is practically identical to that of a virgin sample, the curve gained for a sample treatment at $100^{\circ} \mathrm{C}$ dramatically differs. Regarding the fact that this is the temperature at which the process of cold crystallization starts or already exists, hence primarily, the increased macromolecular mobility and enlarged hydrodynamic volume enables an easier penetration of the oil molecules between polymer chains. The additional plasticizer effect of olive oil reflects through tremendously increased dielectric losses detected by the appearance of a noticeably defined peak in the temperature region between 30 and $80{ }^{\circ} \mathrm{C}$ (Figure 4). The second peak indicating the end of the crystallization process practically overlaps to the cold crystallization peak for untreated and treated sample at $50{ }^{\circ} \mathrm{C}$. The crystallization process for the sample treated at $175{ }^{\circ} \mathrm{C}$ is almost completed, so the peak on $\operatorname{tg} \delta-T$ dependence is significantly smaller and shifted toward higher
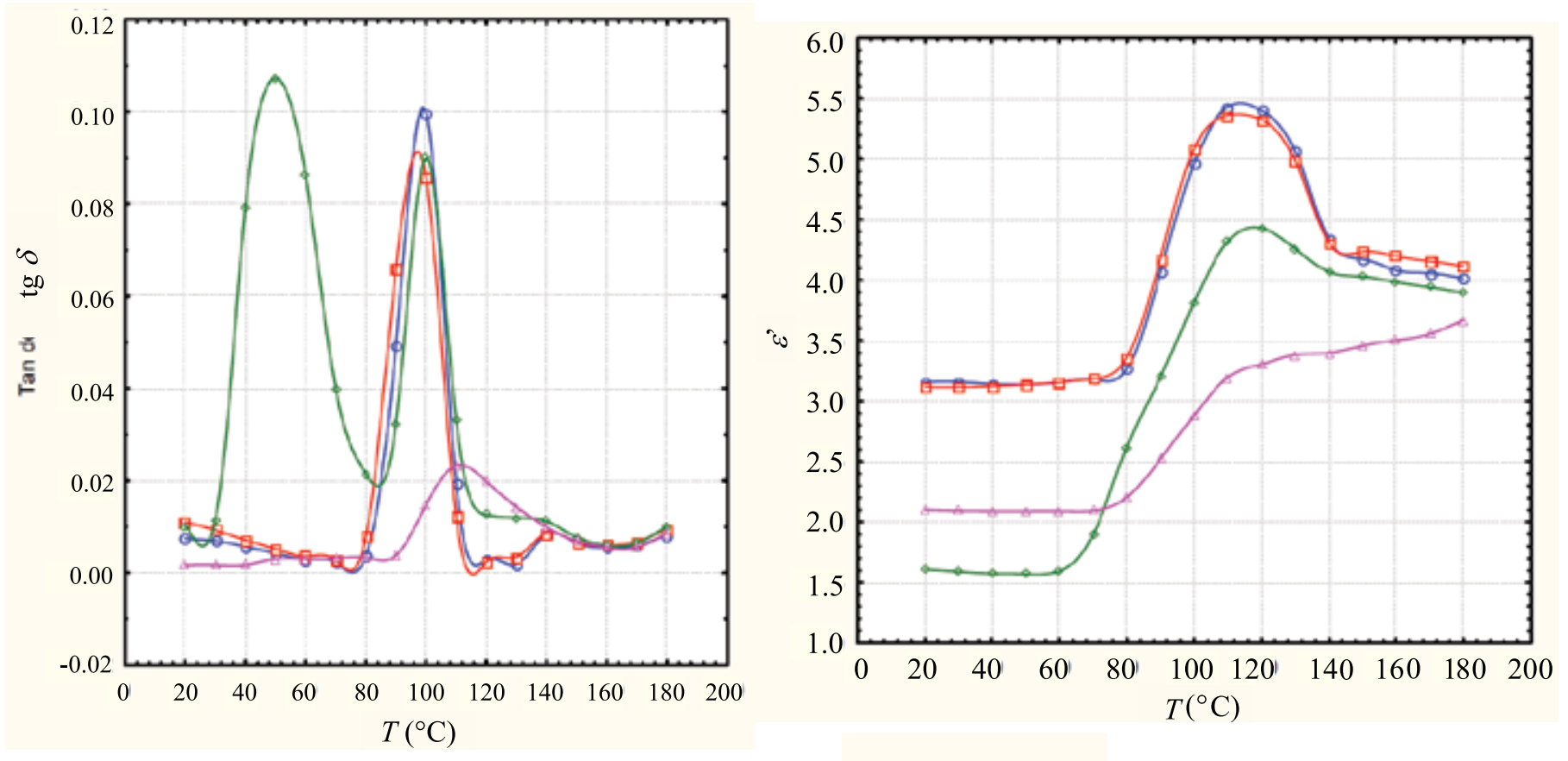

$$
\begin{aligned}
& \mathrm{a}^{\varepsilon^{\prime}-\mathrm{k}} \\
& \mathrm{c} \varepsilon^{\prime}-\mathrm{k}-50-\mathrm{m} \\
& \mathrm{\varepsilon} \varepsilon^{\prime}-\mathrm{k}-100-\mathrm{m} \\
& \varepsilon^{\prime}-\mathrm{k}-150-\mathrm{m}
\end{aligned}
$$

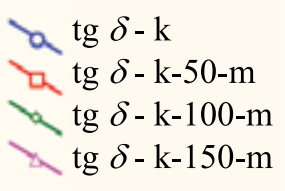

Fig. 4. $\operatorname{tg} \delta$ - $T$ and $\varepsilon^{\prime}-T$ dependences for PET food container untreated (k) and treated in olive oil $2 \mathrm{~h}$, at 50,100 and $175^{\circ} \mathrm{C}(\mathrm{k}-50, \mathrm{k}-100$ and $\mathrm{k}-175)$, heating rate $5^{\circ} \mathrm{C} / \mathrm{min}$ 
temperatures (Figure 4). Changes in the dielectric permittivity (Figure 4) correspond to the already discussed changes in dielectric losses.

Our subsequent analyses were concentrated on a determination of a suitability of a relevant media in simulation of real foodstuff by their impact on the PET structure at different testing conditions (temperature and time), detected again by the means of the DET analysis. Therefore, besides olive oil, 95\% ethanol, 3\% acetic acid, and isooctane were used as the conventional fatty food simulants, while our selection of the real food was mayonnaise as a dominant component in creamy salads, mainly packed in PET containers. Testing conditions have been already summarized in the Table 1.
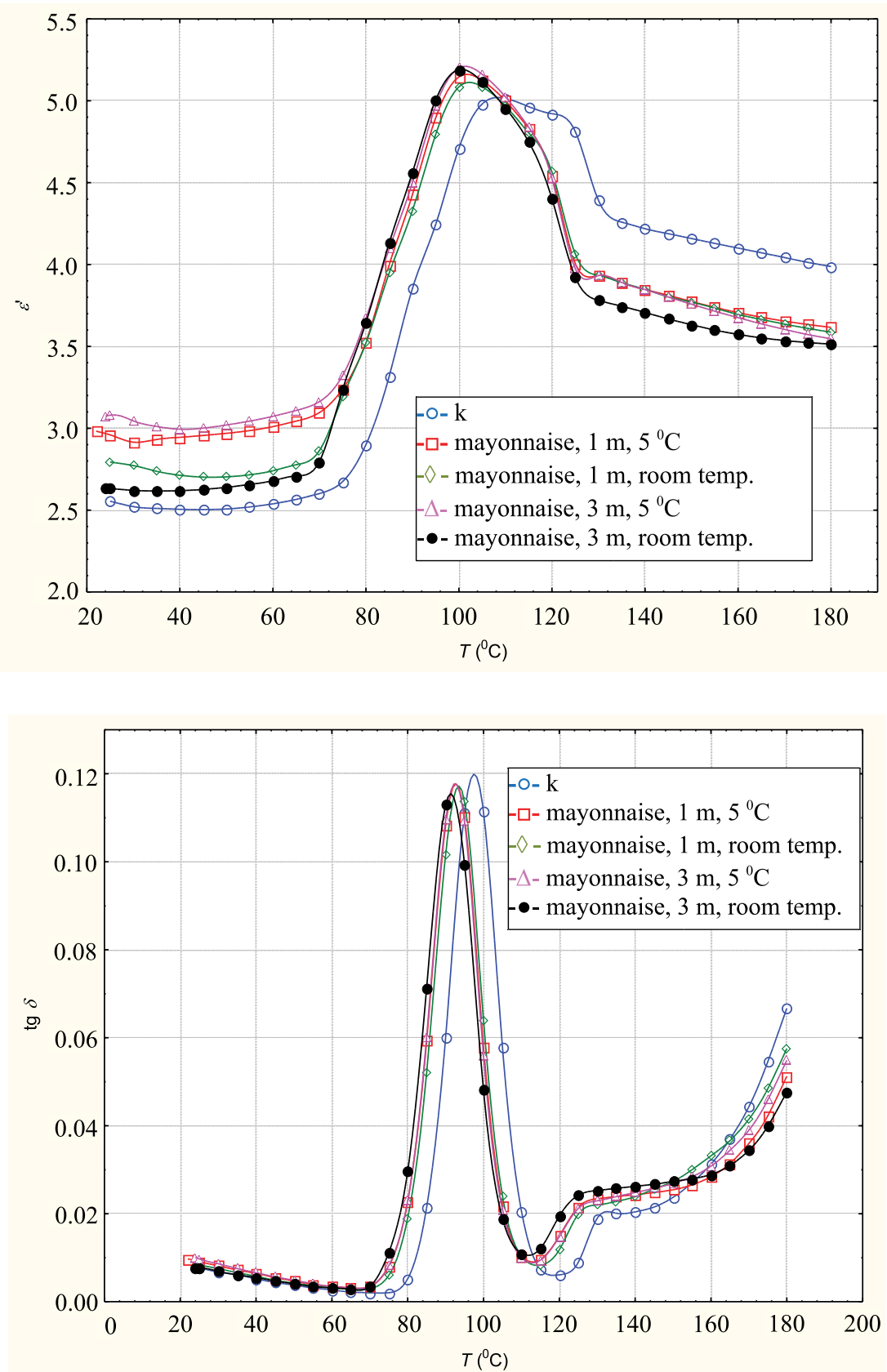

Fig. 5. $\varepsilon^{\prime}-T$ and $\operatorname{tg} \delta-T$ dependences for PET food container untreated (k) and treated in mayonnaise one and three months at $5^{\circ} \mathrm{C}$ and room temperature, heating rate $5{ }^{\circ} \mathrm{C} / \mathrm{min}$ 

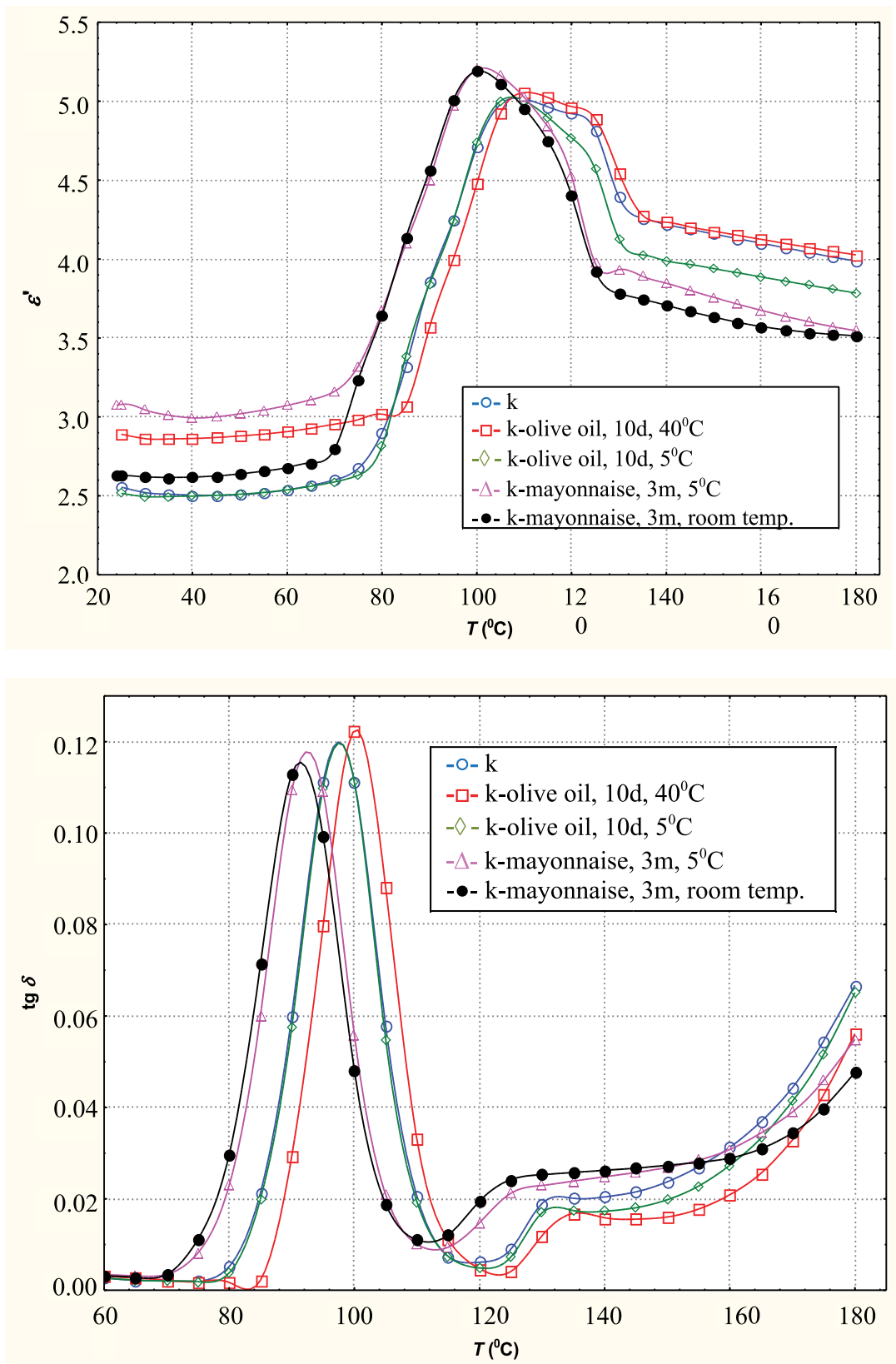

Fig. 6. $\varepsilon^{\prime}-T$ and $\operatorname{tg} \delta$ - $T$ dependences for PET food container untreated $(\mathrm{k})$ and treated in olive oil 10 days, at 5 and $40^{\circ} \mathrm{C}$, and mayonnaise 3 months at $5^{\circ} \mathrm{C}$ and room temperature, heating rate $5^{\circ} \mathrm{C} / \mathrm{min}$

The dielectric behavior of PET samples treated in mayonnaise for one and three months at $5{ }^{\circ} \mathrm{C}$ and room temperature, and those of untreated test tubes are presented on Figure 5. A big difference in the $\varepsilon^{\prime}-T$ and $\operatorname{tg} \delta$ - $T$ dependences for samples treated one and three months were not noticed. So in the following figures of comparison with the behavior in different simulants, it was chosen only the features of the samples treated three months in mayonnaise to be presented.

The responses of PET samples on the treatment in olive oil for $24 \mathrm{~h}$ and 10 days were similar, which was shown for 2 and 3 months as well. Consequently, it was selected only the reaction of the polymer to a treatment in olive oil for 10 days and 3 month to be compared with the sample in contact with the foodstuff (Figs. 6 and 7). 

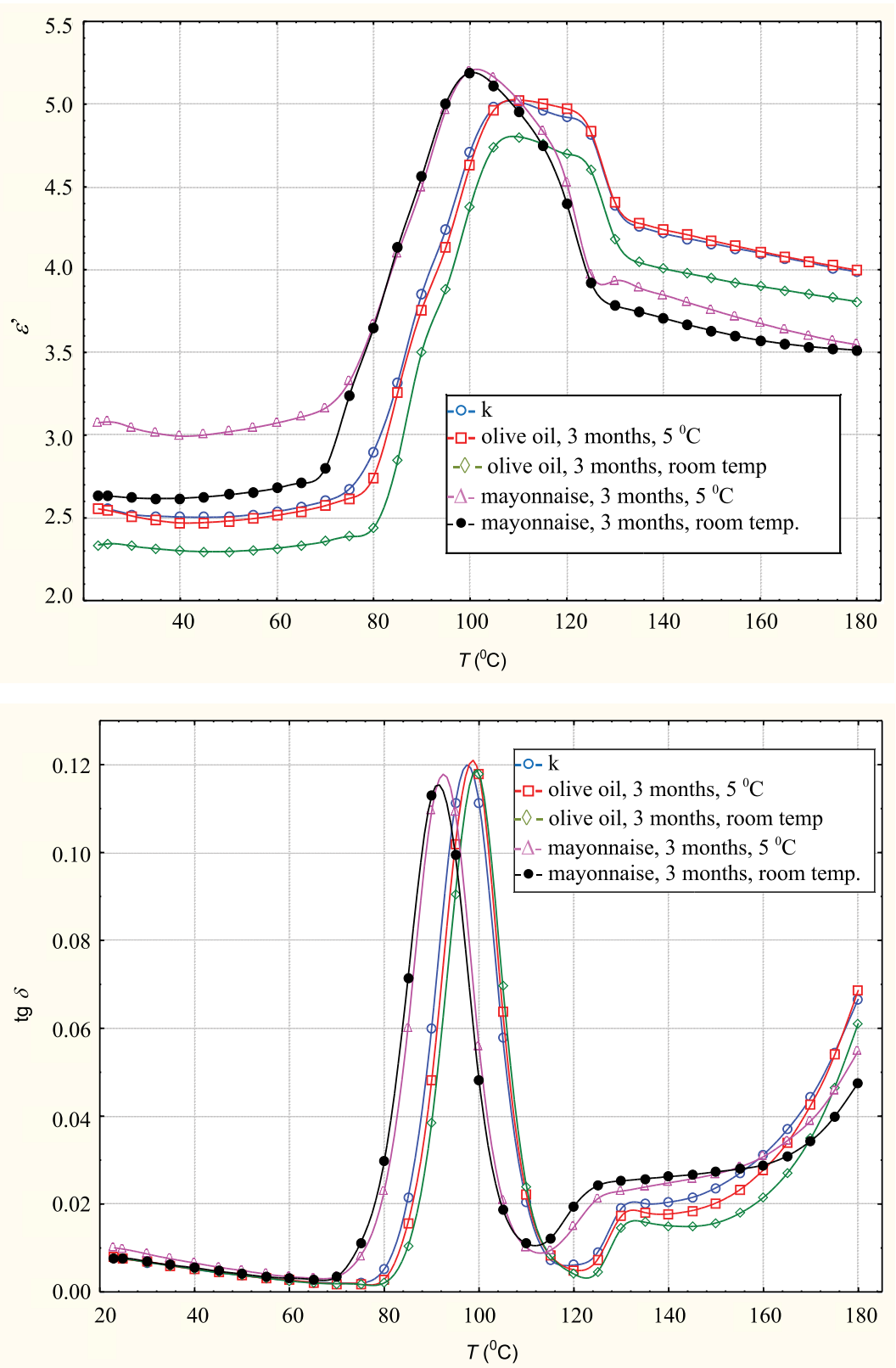

Fig. 7. $\varepsilon^{\prime}-T$ and $\operatorname{tg} \delta-T$ dependences for PET food container untreated (k) and treated in olive oil and mayonnaise, three months at $5{ }^{\circ} \mathrm{C}$ and room temperature, heating rate $5{ }^{\circ} \mathrm{C} / \mathrm{min}$

As it can be seen, the mayonnaise which is a combination of oily and acidic components is a slightly more aggressive medium than a pure olive oil. Namely, olive oil is mainly composed of a mixture of unsaturated fatty acids and owing to their bulky molecules slowly diffuse into the polymer.

The sample treated with isooctane (Figure 8 ) shows the similar behavior as in the contact with olive oil. Both, olive oil and isooctane are nonpolar mediums and their interaction with polar polymer, such as PET is retarded.

On the other hand, the last two simulants we used, acetic acid and ethanol, are both smaller and polar molecules which can easily enter between polar polymer chains, assisting the relaxation and restructuration of the macromolecules. 

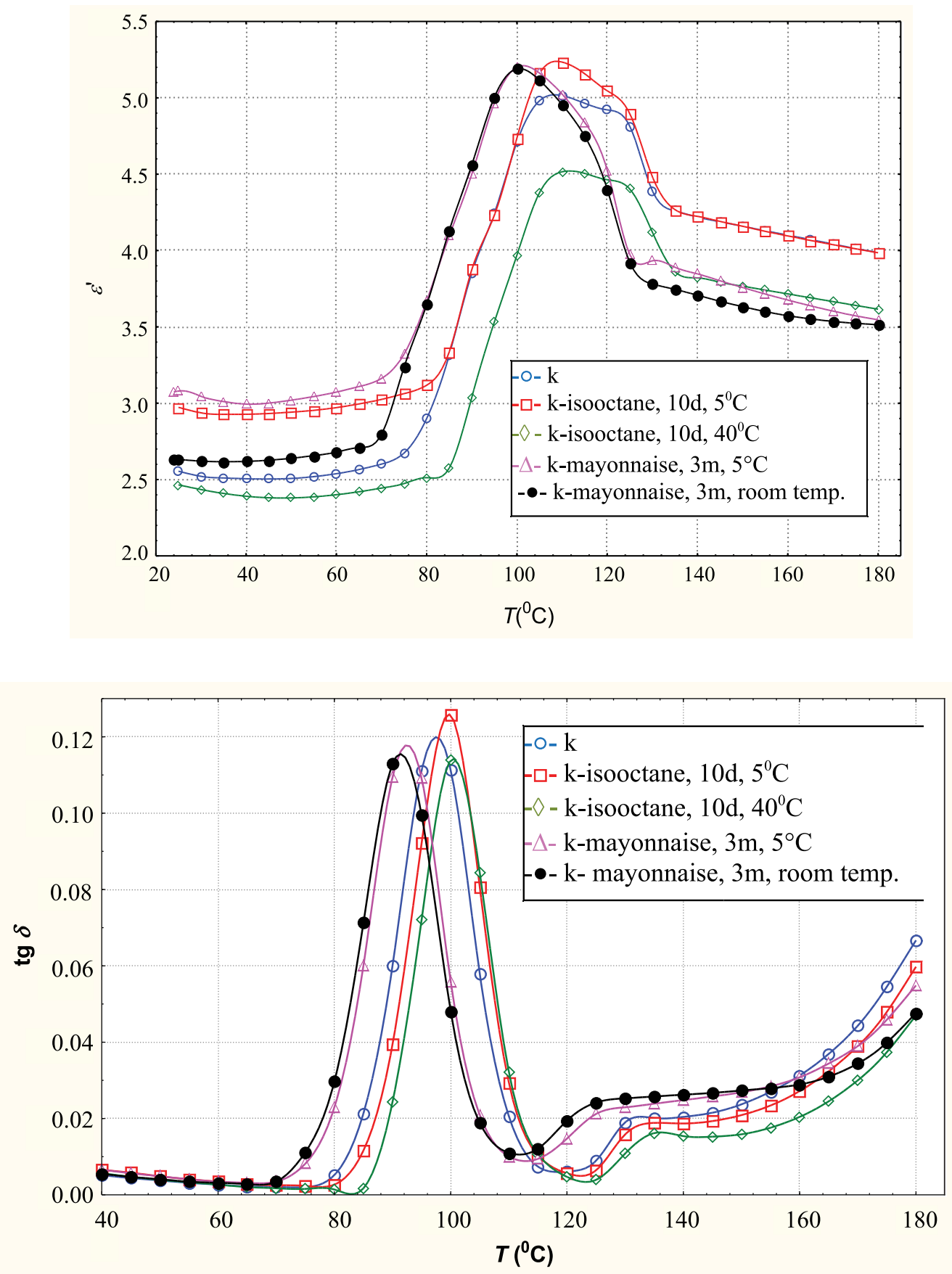

Fig. 8. $\varepsilon^{\prime}-T$ and $\operatorname{tg} \delta-T$ dependences for PET food container untreated (k) and treated in isooctane 10 days, at 5 and $40^{\circ} \mathrm{C}$, and mayonnaise 3 months at $5^{\circ} \mathrm{C}$ and room temperature, heating rate $5^{\circ} \mathrm{C} / \mathrm{min}$

That was confirmed by the $\operatorname{tg} \delta-T$ and $\varepsilon^{\prime}-T$ curves, for the sample in contact with acetic acid for 10 days and $40{ }^{\circ} \mathrm{C}$ shown on Figure 9, specifying the start of the relaxation processes as a result of increased PET chains mobility and plasticizer effect of acetic acid.
The peak of $\varepsilon^{\prime}-T$ dependence shifted toward lower temperatures indicate the occurrence of the relaxation processes supported by the acetic acid. The above mentioned processes and the additional restructuring of a system for a sample treated 10 days at $40{ }^{\circ} \mathrm{C}$ start at slightly lower 

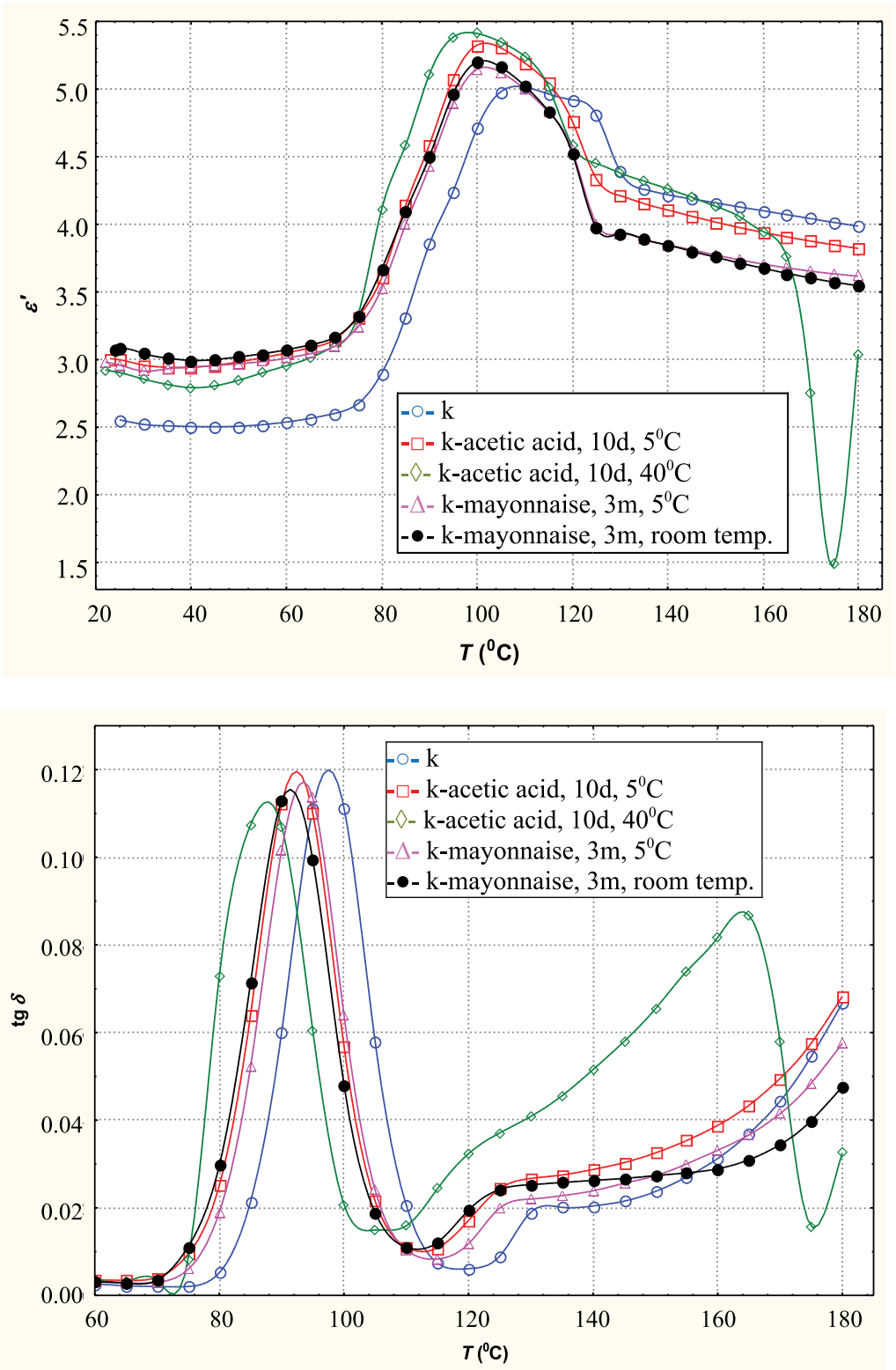

Fig. 9. $\varepsilon^{\prime}-T$ and $\operatorname{tg} \delta-T$ dependences for PET food container untreated (k) and treated in acetic acid 10 days at 5 and $40^{\circ} \mathrm{C}$ and mayonnaise treated 3 months at $5{ }^{\circ} \mathrm{C}$ and room temperature, heating rate $5{ }^{\circ} \mathrm{C} / \mathrm{min}$

temperatures (first peak between 80 and $90{ }^{\circ} \mathrm{C}$ ) and complete at higher temperatures (the second peak from $\sim 110$ to $\sim 160{ }^{\circ} \mathrm{C}$ ), compared to the untreated sample, samples treated in acetic acid at $5{ }^{\circ} \mathrm{C}$ or samples treated with mayonnaise.

Anyway, the performance of the polymer samples interacting with acidic simulant didn't correspond to the actual behavior of a polymer in contact with the real foodstuff (mayonnaise).
The emphasized interaction between small ethanol molecule and polymer is presented on Figure 10. The first peak on $\operatorname{tg} \delta-T$ curve $\left(\sim 70{ }^{\circ} \mathrm{C}\right)$ for sample treated with ethanol at $40{ }^{\circ} \mathrm{C}$ correspond to a beginning of polymer chain relaxation and restructuring assisted by ethanol, while the second wide peak is a result of completeness of the process of cold crystallization. This behavior is confirmed by 

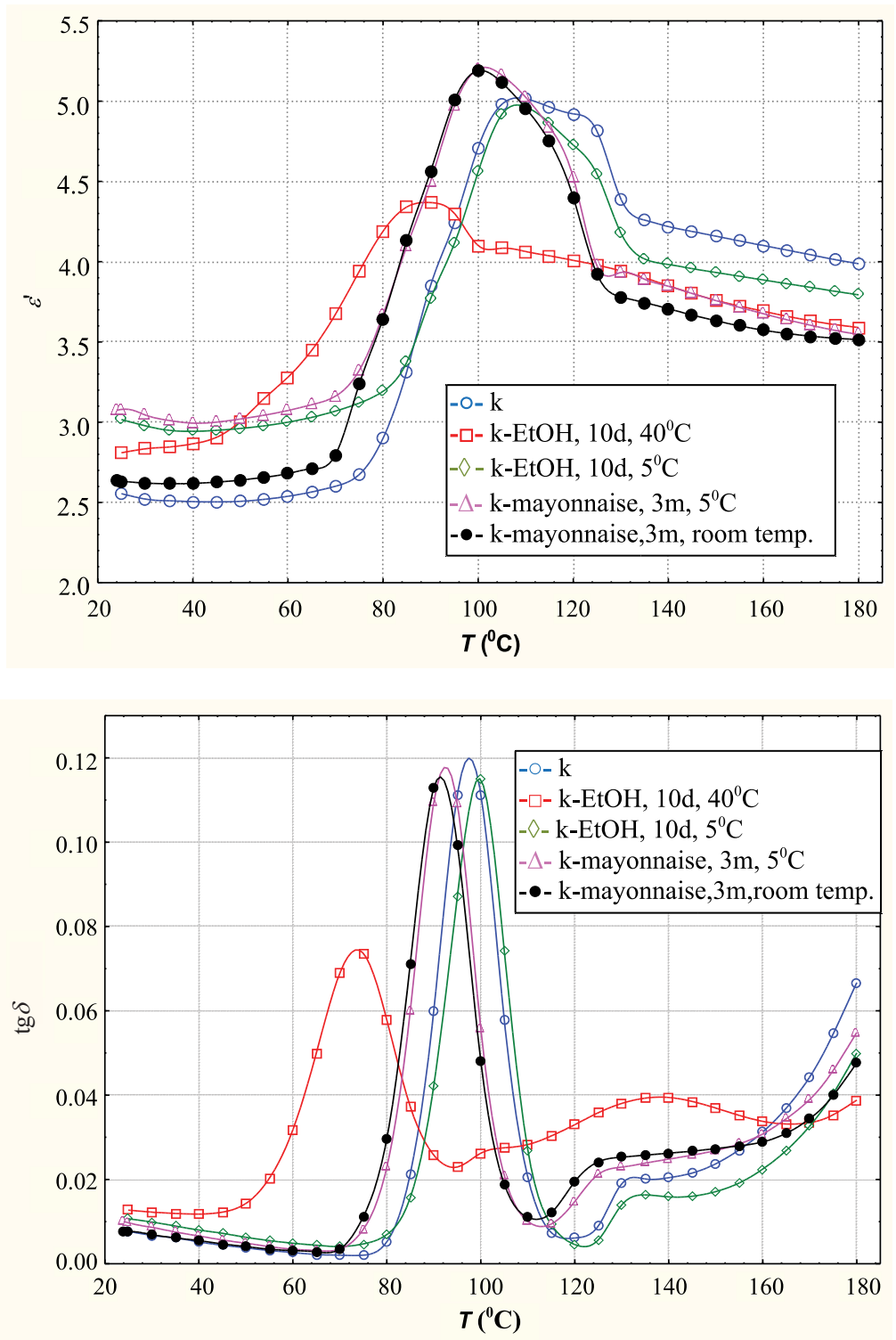

Fig. 10. $\varepsilon^{\prime}-T$ and $\operatorname{tg} \delta-T$ dependences for PET food container untreated (k) and treated in ethanol 10 days at 5 and $40{ }^{\circ} \mathrm{C}$ and mayonnaise treated 3 months at $5{ }^{\circ} \mathrm{C}$ and room temperature, heating rate $5{ }^{\circ} \mathrm{C} / \mathrm{min}$

$\varepsilon$ '- $T$ dependences. Comparing the behavior of samples immersed in ethanol and that in contact with mayonnaise, the mismatch of the degree of interactions between media and polymer again can be noticed, which is to be expected since ethanol is polar and has much smaller molecules.

It is obvious that a single medium is not suitable for simulation of a fatty food with complex composition such as mayonnaise, so the adjustment of appropriate fatty food simulants can be very challenging and exciting process, especially in the application of mixtures of solvents with different polarity.

\section{CONCLUSIONS}

It was shown that dynamic electrical thermal analysis (DETA) can indicate structural changes into poly(ethylene terephthalate) (PET) packaging material, exposed to certain conditions related with packaging applications, which could promote migration of potential food contaminants from PET. 
Therefore the fine correlations between the dielectric properties of PET containers in contact with fatty food and fatty food simulants could indicate the risk for possible migration of contaminants from PET into the foodstuffs and could help to choose the appropriate simulant for studying the migration into certain food.

PET test tubes were subjected, at different conditions, to different polar and apolar media (olive oil, isooctane, acetic acid and ethanol), acting as a conventional fatty food simulants. Dielectric properties of PET containers, treated in this way, were compared to those treated with a real foodstuff (mayonnaise). It was shown that olive oil and isooctane as apolar simulants with their bulky and inert molecules are less aggressive, while the polar solvents we used, acetic acid (3\%) and ethanol (96-97\%) are too aggressive compared to mayonnaise. This suggests that a single medium is not appropriate in the attempts to mimic the characteristics of fatty food with complex composition like mayonnaise. Therefore a probe of mixture of different media as a simulant for fatty foodstuff could be very challenging.

Acknowledgement. The authors express their gratitude to the managers and employees in the company MEGA B\&V for providing the samples used in this study.

\section{REFERENCES}

[1] E. A. Tehrany and S. Desorby, Partition coefficients in food / packaging systems: a review, Food Addit.Contam., 21, 1186-1202 (2004).

[2] R. Franz, F. Welle, Migration measurement and modeling from poly(ethylene terephthalate) (PET) into soft drinks and fruit juices in comparison with food simulants, Food Addit.Contam., 25, 10331046 (2008).

[3] C. Simoneau, P. Hannaert, Stability testing of selected plastics additives for food contact in EU aqueous, fatty and alternative simulants, Food Addit.Contam., 16, 197-206 (1999).

[4] Poly(ethylene terephthalate) (PET) for Food Packaging Applications, Report on Packaging Materials, ILSI Europe Report Series (2000) Avenue E.
Mounier 83, Box 6, B-1200 Brussels.

[5] M. Haldimann, A. Blanc, V. Dudler, Exposure to antimony from polyethylene terephthalate (PET) trays used in ready-to-eat meals, Food Addit. Contam., 24, 860-868 (2007).

[6] C. Simoneau, Recent Developments in the Analysis of Specific Migrants from Food Contact Materials, Safe technopack Brokerage event, JRC (2009) Istanbul, Turkey.

[7] Directive 97/48/EC amending for the second time Council Directive 82/711/EEC laying down the basic rules necessary for testing migration of the constituents of plastic materials and articles intended to come into contact with foodstuffs, O.J. L222, European Commission, Brussels, Belgium, 10-15 (1997).

[8] Migration Testing with Conventional and Alternative Fatty Food Simulants, Research Report N33, European Commission, Brussels, Belgium (1994).

[9] A. M. Riquet, D. Scholler, A. Feigenbaum, Tailoring fatty food simulants made from solvent mixtures (2): determining the equivalent migration behavior of olive oil and of solvents in the case of polyolefins, Food Addit. Contam., 19, 582-593 (2002).

[10] N. H. Stoffers, M. Dekker, J. P. H. Linssen, A. Stormer, R. Franz, Alternative fatty food simulants and diffusion kinetics of nylon 12 food packaging, Food Addit. Contam. 20, 949-959 (2003).

[11] A. P. Arora, J. W. Halek, Structure and cohesive energy density of fats and their sorption by polymer films, J. Food Sci., 29, 1325-1327 (1994).

[12] R. Gavara, R. Catalá, P. Hernández-Muñoz, Study of aroma scalping through thermosealable polymers used in food packaging by inverse chromatography, Food Addit. Contam., 14, 609-616 (1997).

[13] A. Porjazoska, T. Grčev, M. Cvetkovska, O. KaralYilmaz, M. B. Baysal, Thermal aging of poly(D,Llactide-co-glycolide) films followed by impedance spectroscopy and dielectric thermal analysis, Bull. Chem. Technol. Macedonia, 21, 199-206 (2002).

[14] C. Alvarez, J. Sies, A. Nogales, Z. Denchev, S. S. Funari, A. T. Ezquerra, Structure-dynamics relationship in crystallizing poly(ethylene terephthalate) as revealed by time-resolved X-ray and dielectric methods, Polymer, 45, 3953-3959 (2004).

[15] J. Majszczyk, A. Kozlowska, Mechanical and Dielectric Properties of some New Poly(AmideBlock-Ester) Thermoplastic Elastomers, Rev. $A d v$. Mater. Sci., 12, 139-144 (2006). 
[16] B. Wunderlich, Thermal analysis of polymeric materials, Springer, Berlin-Heidelberg-New York, Printed in Netherland, 2005.

[17] D. Čamovska, T. Grčev, M. Cvetkovska, Mogućnosti dielektrične termičke analize za karakterizaciju poli(etilen tereftalata), Zaštita materijala, 52, 247-256 (2011).
[18] Handbook of plastics, elastomers and composites, $4^{\text {th }}$ ed., Charles A. Harper (Ed.), McGraw-Hill, New York, 2002.

[19] N. Oureshi, V. E. Stepanov, D. Schiraldi, A. Hiltner, E. Baer, Oxygen-barrier properties of oriented and heat-set poly(ethylene terephthalate), J. Polym. Sci., Part B: Polym. Phys. 38, 1679-1686 (2000). 
